\title{
Teachers and students' perceptions about feedback in clinical internships in medical school
}

Percepções de docentes e discentes sobre feedback em estágios práticos no curso de medicina

\author{
Simone Stagini' (1) $\mid$ sstagini@gmail.com \\ Lena Vânia Carneiro Peres' ${ }^{1}$ (D) lena.agenda@gmail.com
}

\begin{abstract}
Introduction: In medical education, feedback is considered one of the main types of formative assessment. Feedback can be defined as the transmission of information by observing students in action aiming to provide improvement for the acquisition of medical skills that constitute medical professionalism.
\end{abstract}

Objective: The aim of this study was to assess if there are difficulties in transmitting and receiving feedback by preceptors and students during the practical stages of medical training.

Methods: This qualitative / quantitative design study involved all students who completed the internship from March 2018 to August 2019 ( $n=$ 50), as well as all preceptors responsible for the internships $(n=9)$ at Universidade Municipal de São Caetano do Sul. Knowledge about feedback, according to the viewpoint of students and preceptors, was assessed using adapted questionnaires with categorical and open questions. Descriptive analyses were used for the quantitative data and the content technique for the qualitative data.

Results: The preceptors report that the objectives of providing feedback are to point out improvement, critical reflection, and opportunity for adjustments. Meanwhile, students report: clarification of doubts, planning for improvements and knowledge of positive points. Half of the preceptors claim to provide very frequent feedback, but students would like to receive feedback more often. Students want feedback to be constructive and private. Half of the preceptors find it difficult to give negative feedback; however, $60 \%$ of the students report handling criticism well.

Conclusion: The preceptors declare to have knowledge of and know about the objectives of giving feedback; however, they have difficulties communicating it, especially when it involves criticisms for the correction of behaviors and attitudes. The students accept criticism and would like feedback to be conveyed more often in the practical stages. It is necessary to improve the process of providing and receiving feedback.

Keywords: Education Measurement; Formative Feedback; Medical Education Undergraduate; Faculty Medical; Medical Students.

\section{RESUMO}

Introdução: No ensino médico, feedback - ou devolutiva - é um dos componentes principais da avaliação formativa. Feedback pode ser definido como transmissão de uma informação quando se observam os estudantes em ação, a fim de propiciar melhorias para aquisição de competências médicas que compõem o profissionalismo médico.

Objetivo: Este estudo teve como objetivo avaliar se há dificuldades de transmissão e recepção de feedback pelos preceptores e estudantes durante os estágios práticos do curso de Medicina.

Método: Este estudo de delineamento misto qualitativo/ quantitativo envolveu todos os discentes que concluíram os estágios no período de março de 2018 a agosto de 2019 ( $n=50)$, assim como todos os preceptores responsáveis pelos estágios práticos $(n=9)$ da Universidade Municipal de São Caetano do Sul. O conhecimento sobre feedback, na visão dos discentes e preceptores, foi avaliado por meio de questionários adaptados com perguntas categóricas e abertas. Utilizaram-se análise descritiva nos dados quantitativos e técnica de conteúdo nos dados qualitativos.

Resultado: Os preceptores relataram que os objetivos de fornecer feedback são: apontamento de melhoria, reflexão crítica e oportunidade de adequações. Por sua vez, os estudantes relataram: esclarecimento de dúvidas, planejamento de melhorias e conhecimento de pontos positivos. Metade dos preceptores afirmou fornecer feedback, porém os estudantes gostariam de recebê-lo de forma mais contínua. Os estudantes desejam que o feedback seja construtivo e feito em local privado. Metade dos preceptores tem dificuldade em dar feedback negativo, porém $60 \%$ dos estudantes relataram lidar bem com críticas.

Conclusão: Os preceptores afirmaram ter conhecimento dos objetivos do feedback. Porém, eles têm dificuldades para transmiti-lo, principalmente quando envolve críticas para correções de comportamentos ou atitudes. Os estudantes aceitam críticas e requerem que o feedback seja transmitido com mais frequência nos estágios práticos. Há a necessidade de melhorar o processo de fornecer e receber feedback.

Palavras-chave: Avaliação Educacional; Feedback Formativo; Educação de Graduação em Medicina; Docentes de Medicina; Estudantes de Medicina.

1 Universidade Municipal de São Caetano do Sul, São Caetano do Sul, São Paulo, Brazil.

Chief Editor: Rosiane Viana Zuza Diniz.

Associate Editor: Roberto Zonato Esteves.

Received on 10/13/20; Accepted on 05/22/21.

Evaluated by double blind review process. 


\section{INTRODUCTION}

Since the establishment of the Portuguese court in Brazil, several changes have taken place in Brazilian medical education, including the Flexenerian reform implemented during the military regime, which proposed a university-based medical school with a pedagogical scientific-based program and a four-year course, two dedicated to the basic areas and two to practical activities. During this period, medical education was based on diseases and the medicalization aiming at their cure, without considering the individual's psychosocial aspects'.

In 1988, with the creation of the Unified Health System in Brazil, the implemented health model started to cover the entire population, taking into account the individual health needs and the individual's psychosocial character ${ }^{2}$, and thus, it became necessary to train doctors to meet these needs, which was materialized with the National Curriculum Guidelines (NCGs) for undergraduate medical school from 2001 and 2014. These NCGs proposed the training of general practitioners to work in the prevention, promotion, recovery and rehabilitation of the patient ${ }^{3,4}$. Due to the NCGs, which came into effect on December 31, 20184, the student became the main actor of their learning, with the teacher being a supporting actor, a facilitator of the teaching and learning process, through which the student starts to be evaluated according to the skills acquired in learning, in addition to using active teaching methodologies $1,3,5$.

In order to determine whether or not the student has achieved the desired competences for medical training, an assessment is required. With the implementation of the NCGs, the assessments are no longer just aimed at attaining passing grades to find out whether the student is able or not to move on to another stage of the course, but becomes a formative assessment, aiming to investigate failures during practical activities, so that they are reflected by the students through the assimilation of concepts and scenarios that have been experienced and promote behavior changes, so that the desired skills are achieved ${ }^{6}$. The main characteristic of this type of assessment is the use of a learning instrument called feedback, which is performed immediately after an activity?.

Feedback in medical practice can be defined as the transfer of data observed by preceptors during medical practice, contextualizing cognitive knowledge, practical skill, decision making and whether the learning objectives were achieved, aiming at a student's reflection, so they can rebuild their knowledge and change their way of acting, improving their performance so that they can attain the necessary skills for the profession for the patient's benefit ${ }^{8}$. Feedback is important for students to reflect on their performance, what is the desired performance and to seek support to improve their resourcefulness in practical environments. Secondarily, feedbacks are important for students to act autonomously, through self-reflection and continuous learning ${ }^{6}$. Its objective is to emphasize good medical practices, appreciating the students' good performance and promoting a critical reflection on the aspects that need improvement, in addition to how they can be improved ${ }^{6,9}$.

For feedbacks to be effective, the rapport between teacher and student is necessary, as well as a clear communication, the student's understanding and identification of the learning objectives that are desired by both the student and the preceptor ${ }^{8}$. Moreover, the time devoted to the observation, the place where the feedback was carried out, the content and type of feedback communication also influence the feedback effectiveness. Therefore, there are several obstacles to providing and receiving an effective feedback. There are reports that many preceptors are unaware of or are not used to communicating feedback to students ${ }^{11,12}$. Furthermore, many students do not understand that they are receiving feedback ${ }^{8}$. Therefore, aiming to build proposals for the improvement of giving and receiving feedback, the main objective of the study was to evaluate the perception of preceptors and students at the USCS - Bela Vista, about the feedbacks in internships in Diadema.

\section{METHODS}

\section{Type of study}

A qualitative-quantitative cross-sectional study was carried out aiming to analyze the perception of a group of medical students and teachers about feedback. This study was approved by the Research Ethics Committee of Universidade Municipal de São Caetano do Sul (USCS). Opinion Number: 3.551.101 and REC protocol: 17717019.8.0000.5510.

\section{Location}

Data from this sample were collected from four public health sites: the Municipal Hospital of Diadema (HMD), the Municipal Emergency Department of Diadema (Central ED), the Mobile Emergency Care System (SAMU, Sistema de Atendimento Móvel de Urgência) of the municipality of Diadema and the Psychosocial Care Center (CAPS, Centro de Atenção Psicossocial), both located in the city of Diadema, municipality of São Paulo, southeastern Brazil.

\section{Eligibility Criteria}

Medical undergraduate students from USCS attending the seventh and eighth semesters (Bela Vista Campus) and who had already attended the following clinical internships in Diadema: Internal Medicine - HMD, Pediatrics - Central PS, 
SAMU (Emergency Mobile Care Service) and CAPS (Psychosocial Care Centers), from March $5^{\text {th }}, 2018$, to August $21^{\text {st }}, 2019$, who agreed to participate in the research and signed the consent form, were included in the study. Also included in this study were the hired and/or tenured USCS preceptors responsible for practical internships during the same periods and in the same places who agreed to participate in the research.

Students attending the $7^{\text {th }}$ semester that had not finished all internships (Internal Medicine, Pediatrics, SAMU and CAPS) during the study evaluation period were not included in this investigation. Students and/or preceptors who did not sign the free and informed consent form or who did not accept to participate in the research were excluded from the study.

\section{Procedures}

Potential individuals selected for this study were invited to participate in the investigation via WhatsApp. Questionnaires for the evaluation were provided to students at the University Secretary Office and provided to preceptors at their respective workplaces. From March $5^{\text {th }}$ to August $21^{\text {st }}$, five groups of students went through the four practical internships, totaling fifty students. Of these, thirty students agreed to participate in the study and answered the questionnaire. Among the nine preceptors responsible for the practical internships, eight agreed to participate and were included in this study.

The evaluation questionnaires were based on questions by Maia et $\mathrm{al}^{13}$. The questions were adapted to categorical and qualitative questions in two questionnaires, being one for preceptors and one for students. The questionnaire adapted for student assessment contained 11 categorical questions and eight open questions that evaluated feedback. All categorical questions had five items as answer options that varied between "completely agree", "agree", "neither agree nor disagree", "disagree" and "completely disagree". The content of the questions asked to the students was whether they were aware of what feedback was and the goals of receiving it. How often they received feedback during the internships and what was the impact (positive and negative) of feedback on their practice. What situations made students uncomfortable during the practice of feedback and if they knew how to handle criticism when receiving feedback. It was also evaluated whether students noticed any changes in their practice after receiving feedback and whether they would like the feedback to be a constant practice. Moreover, what characteristics or qualities a preceptor should have and how the student would like to receive feedback were assessed. Finally, it was also evaluated whether the students were able to provide feedback to the teacher and whether they had already noticed any changes in the teacher after receiving their feedback. More details about the questionnaire applied to students can be seen in (Appendix 1).

To assess the preceptors, a socio-demographic questionnaire was applied, followed by the same version of Maia's questionnaire, after being modified and adapted for the preceptors and containing nine categorical questions and six open questions ${ }^{13}$. All categorical questions had five items as answer options that varied between "completely agree", "agree", "neither agree nor disagree", "disagree" and "completely disagree". The content of the questions asked to the preceptors was how much knowledge they had and whether they knew how to provide feedback. How often they provided feedback or how else they assessed students. It was also assessed whether the preceptors knew the different ways to provide feedback, which ones they used and whether they could identify whether the feedback provided was effective for the student. Moreover, it was assessed whether the preceptors identified specific characteristics in the student to benefit from feedback and what were these characteristics. It was evaluated whether the preceptors had difficulties in offering negative feedback to the students and in which situations, and finally, it was evaluated whether the preceptor requested feedback from the students and whether they intended to modify their practice as a preceptor after the student's feedback.

The primary study variables were questions regarding the difficulties met by students and preceptors in receiving and providing feedback, respectively. The secondary variables comprised the frequency of receiving and offering feedback, the preceptors' experience with feedback, change in student behavior and what characteristics the preceptor and the student must have.

\section{Statistical Analysis}

Quantitative data from this study were analyzed using frequency analysis for categorical data, which calculates absolute numbers and percentages for each assessed question; and through descriptive analysis for continuous data, calculating the mean and standard deviation of each variable.

The qualitative statistical analysis was performed in 3 steps: (1) transcribing and organizing data into thematic units (words or phrases that described the topics present in the participants' responses); (2) data exploration, which involved careful reading and organization of data into categories (these categories were created according to the frequency of thematic units identified in step 1 and using the content technique. This technique analyzes the data using the frequency inference method and also through the analysis by thematic categories ${ }^{14}$; and (3) data interpretation and summarization. All authors approved the thematic units and categories created during data analysis ${ }^{15}$. 


\section{RESULTS}

A total of 59 individuals were invited to participate in this study, as shown in Figure 1. However, only 38 agreed to participate and were included for data analysis in this study, eight preceptors and 30 students. The main reason that some

Figure 1. Study flowchart.

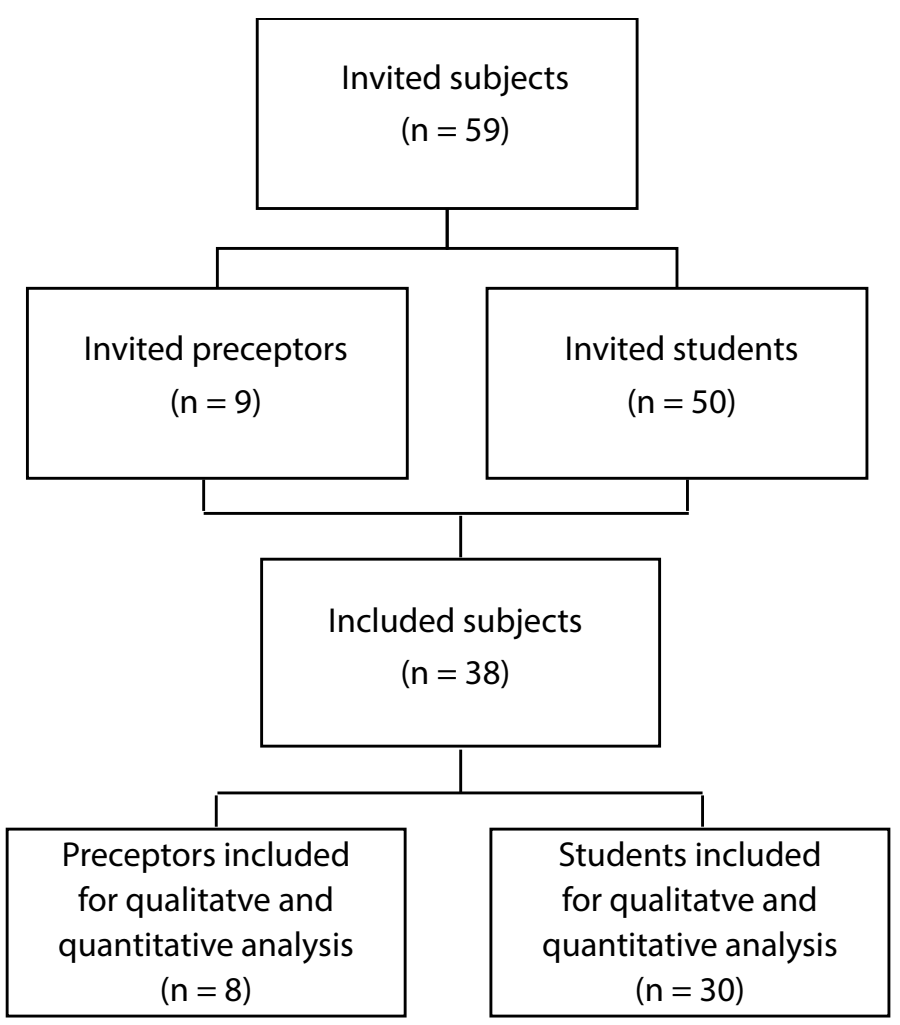

invited individuals did not participate in the study was because the potential participant did not respond to contact attempts via email or WhatsApp.

\section{Preceptors' results}

The preceptors included 4 men and 4 women, with a mean age of 39 years ( $S D=5.4)$. Most were physicians $(75 \%)$, the level of schooling varied between postgraduate education and residency, both comprehending $75 \%$ of the teachers, to master's degree $(37.5 \%)$ and doctoral degree (25\%). A total of $75 \%$ of the preceptors had experience with health education and of these, the time of experience was on average 23 months ( $S D=39.9$ ).

The preceptors' self-report on feedback knowledge ranged from no knowledge (12.5\%) to a lot of knowledge (25\%). Most preceptors (75\%) agreed that they knew about the objectives of providing feedback. The results on the frequency with which they provided feedback varied greatly according to each teacher; for instance, while $12.5 \%$ of the teachers never provided feedback, $25 \%$ of them provided it in all practical classes. Half of the teachers reported knowing about the different ways to provide feedback to their students, and the majority (37.5\%) reported having no difficulty in providing feedback. Most preceptors (62.5\%) declared that students need to have specific characteristics to benefit from feedback. Additionally, only $12.5 \%$ of teachers reported they have never asked for feedback from the student about their performance as a teacher, and most of them agree to change their behavior after receiving feedback from the student. More details on the preceptors' quantitative results can be found in Table 1.

Table 1. Preceptors' quantitative results.

\begin{tabular}{|c|c|c|c|c|c|}
\hline & $\begin{array}{c}\text { No } \\
\text { knowledge }\end{array}$ & $\begin{array}{c}\text { Little } \\
\text { knowledge }\end{array}$ & $\begin{array}{c}\text { Moderate } \\
\text { knowledge }\end{array}$ & $\begin{array}{c}\text { A lot of } \\
\text { knowledge }\end{array}$ & $\begin{array}{c}\text { Deep } \\
\text { knowledge }\end{array}$ \\
\hline \multirow[t]{2}{*}{1 - Do you know what feedback is? } & $1(12.5 \%)$ & $3(37,5 \%)$ & $2(25 \%)$ & $2(25 \%)$ & $0(0)$ \\
\hline & $\begin{array}{l}\text { I completely } \\
\text { disagree }\end{array}$ & I disagree & $\begin{array}{l}\text { I neither agree } \\
\text { nor disagree }\end{array}$ & I agree & $\begin{array}{l}\text { I completely } \\
\text { agree }\end{array}$ \\
\hline $\begin{array}{l}2 \text { - I am aware of the objectives of providing } \\
\text { feedback }\end{array}$ & $0(0)$ & $0(0)$ & $6(25 \%)$ & $8(75 \%)$ & $0(0)$ \\
\hline 3 - I know the different ways to provide feedback & $0(0)$ & $2(25 \%)$ & $2(25 \%)$ & $4(50 \%)$ & $0(0)$ \\
\hline 4 - I can assess whether my feedback was effective & $0(0)$ & $2(25 \%)$ & $4(50 \%)$ & $2(25 \%)$ & $0(0)$ \\
\hline $\begin{array}{l}5 \text { - Students need to have specific qualities to } \\
\text { benefit from feedback. }\end{array}$ & $1(12.5 \%)$ & $1(12,5 \%)$ & $1(12,5 \%)$ & $5(62,5 \%)$ & $0(0)$ \\
\hline $\begin{array}{l}6 \text {-I have difficulty in providing feedback to the } \\
\text { student }\end{array}$ & $0(0)$ & $3(37,5 \%)$ & $2(25 \%)$ & $2(25 \%)$ & $1(12,5 \%)$ \\
\hline \multirow[t]{2}{*}{$\begin{array}{l}7 \text { - I am willing to change my method of } \\
\text { assessment when a student criticizes my feedback. }\end{array}$} & $0(0)$ & $0(0)$ & $2(25 \%)$ & $4(50 \%)$ & $2(25 \%)$ \\
\hline & Never & Rarely & Occasionally & Very often & $\begin{array}{l}\text { In all practical } \\
\text { activities }\end{array}$ \\
\hline 8 - How often did you provide feedback? & $1(12.5 \%)$ & $2(25 \%)$ & $1(12,5 \%)$ & $2(25 \%)$ & $2(25 \%)$ \\
\hline $\begin{array}{l}9 \text { - How often do you request feedback from } \\
\text { students about your performance as a teacher? }\end{array}$ & 1 (12.5\%) & $2(25 \%)$ & $3(37,5 \%)$ & $2(25 \%)$ & $0(0)$ \\
\hline
\end{tabular}

The results were presented in absolute numbers (percentage). 
Qualitatively, the teachers were instructed to write about several questions when providing feedback to the student during a practical medical internship. The topics discussed with these teachers were: (1) objectives when providing feedback; (2) frequency with which they provided feedback; (3) types of feedback they more often provided; (4) how they assessed whether a feedback was effective; (5) in which situations it was difficult to provide feedback; (6) what qualities a student needs to have to receive an effective feedback. All contents reported in each of the topics are presented in Table 2, as well as the number of citations of each content according to the preceptors' responses.

\section{Students' results}

The students reported having moderate (40\%) to deep (6.7\%) knowledge about feedback, and the majority reported being aware of the objectives of receiving feedback. None of the students reported receiving feedback in all practical classes. According to the students, the feedback had a positive impact on their learning, with $53 \%$ and $40 \%$ of the students agreeing and completely agreeing with it. When asked about the negative impact of feedback on learning, $30 \%$ and $43 \%$ of the students completely disagreed or disagreed with this statement. Most students disagreed with feeling uncomfortable when receiving feedback after a practical performance ( $37 \%$ and $47 \%$ ) and that they handle well receiving negative criticism during feedback $(60 \%$ and $13 \%)$. Most students reported that they observed changes in clinical practice after receiving feedback (57\% and 37\%) and agreed (53\%) and completely agreed (37\%) that feedback should be a constant practice in their course. Finally, the students were asked if they could provide feedback to the

Table 2. Preceptors' qualitative results.

\begin{tabular}{lc}
\hline \multicolumn{1}{c}{ Topics/Content } & Number of citations* \\
\hline Feedback Objectives & \\
Assisting in difficulties & 4 \\
Transmitting reflection on practice & 3 \\
Motivating strengths & 2 \\
\hline Feedback frequency & 2 \\
Always & 2 \\
Whenever necessary & 2 \\
Once per internship & 2 \\
Never & 1 \\
\hline
\end{tabular}

Types of feedback

Oral $\quad 6$

Constructive $\quad 2$

$\begin{array}{ll}\text { Brief } & 2\end{array}$

Evaluating Feedback Effectiveness

To observe attitudes $\quad 6$

$\begin{array}{ll}\text { To ask the student } & 2\end{array}$

Difficulty in providing a negative feedback

Fear of hurting the student $\quad 2$

When the student does not know how to receive criticism $\quad 2$

To correct aspects of the student's personality 1

Student's Qualities to Receive Effective Feedback

$\begin{array}{lr}\text { Active listening } & 4 \\ \text { Interest } & 3 \\ \text { Resilience } & 2 \\ \text { Handling criticism well } & 1 \\ \text { Respect and empathy } & 1\end{array}$

*The number of citations represents the number of times the content was mentioned in the preceptors' responses. This decision was made because the open-ended questions did not limit the number of answers a preceptor could provide. 
preceptor and the answers were varied; some did it and even saw a change in the teacher's practice, but most did not or could not find space and felt insecure to provide feedback to the teacher. More details on the preceptors' quantitative results can be found in Table 3 .

Qualitatively, students were instructed to write about several questions when receiving feedback from the preceptor, during their practical medical internship. The topics discussed with these students were: (1) objectives of receiving feedback; (2) the positive impact of feedback; (3) the negative impact of feedback; (4) what changes are observed after feedback; (5) what are the qualities of the preceptor to provide effective feedback; (6) characteristics of an ideal feedback; (7) characteristics of uncomfortable feedback. All contents reported by students in each of the topics are presented in Table 4, as well as the number of citations of each content.

\section{DISCUSSION}

The current study showed quantitative and qualitative data regarding impediments and suggestions for improvement in feedback assessment during practical internships in undergraduate medical school. The results were reported according to the students' perception on feedback, but also according to the preceptors' perception, since these two viewpoints are not always similar regarding the same concepts. From the preceptors' point of view, the impediments comprising lack of knowledge and inadequacy regarding the ways of approaching feedback were identified, as well as an impediment regarding the lack of effective communication between preceptors and students. From the students' point of view, the identified impediments comprised the frequency of feedback, students expect feedback more often, they do not mind negative feedback if it involves constructive criticism and they prefer the preceptor to assess them individually, without exposing them in the presence of the patient or their colleagues.

Regarding the feedback objectives, the preceptors and the students showed agreement regarding the answers and reported, for instance, that clarifying doubts is one of the objectives, as well as reinforcing the positive aspects of the practical activity, in addition to motivating critical reflection on the performed actions. These concepts are in line with the literature; feedbacks should focus on the student's development in practical activities, informing them about necessary changes that contribute to improve their performance, in addition to motivating students to reflect on how to solve the detected problems ${ }^{16}$. The objectives of the feedbacks also include making students aware of their good practices during the internship and which knowledge domains, be it cognitive, psychomotor

Table 3. Students' quantitative results.

\begin{tabular}{|c|c|c|c|c|c|}
\hline & $\begin{array}{c}\text { No } \\
\text { knowledge }\end{array}$ & $\begin{array}{c}\text { Little } \\
\text { knowledge }\end{array}$ & $\begin{array}{c}\text { Moderate } \\
\text { knowledge }\end{array}$ & $\begin{array}{l}\text { A lot of } \\
\text { knowledge }\end{array}$ & $\begin{array}{l}\text { Deep } \\
\text { knowledge }\end{array}$ \\
\hline 1- Do you know what feedback is? & $0(0)$ & $0(0)$ & $12(40 \%)$ & $16(53.3 \%)$ & $2(6.7)$ \\
\hline $\begin{array}{l}2 \text { - I am aware of the objectives of receiving } \\
\text { feedback }\end{array}$ & $0(0)$ & $0(0)$ & $1(3.3 \%)$ & $19(63.3 \%)$ & $10(33.3 \%)$ \\
\hline 4 - Feedback had a negative impact on my learning & $9(30 \%)$ & $13(43.3 \%)$ & $6(20 \%)$ & $1(3.3 \%)$ & $0(0)$ \\
\hline $\begin{array}{l}\text { 5- I feel uncomfortable receiving feedback after } \\
\text { a practical performance. }\end{array}$ & $11(36.7 \%)$ & $14(46.7 \%)$ & $4(13.3 \%)$ & $1(3.3 \%)$ & $0(0)$ \\
\hline 6 - I handle negative criticism well during feedback. & $0(0)$ & $0(0)$ & $8(26.7 \%)$ & $18(60 \%)$ & $4(13.3 \%)$ \\
\hline $\begin{array}{l}7 \text { - There was a change in my medical practice } \\
\text { after feedback from the preceptors }\end{array}$ & $0(0)$ & $0(0)$ & $2(6.7)$ & $17(56.7 \%)$ & $11(36.7 \%)$ \\
\hline $\begin{array}{l}9 \text { - I would like feedback to be a constant } \\
\text { practice in my course. }\end{array}$ & $0(0)$ & $0(0)$ & $3(53.3 \%)$ & $16(53.3 \%)$ & $11(36.7 \%)$ \\
\hline \multirow[t]{2}{*}{$\begin{array}{l}10 \text { - My teacher has already asked me to provide } \\
\text { feedback on their performance. }\end{array}$} & $5(16.7 \%)$ & $6(20 \%)$ & $6(20 \%)$ & $8(26.7 \%)$ & $4(13.3 \%)$ \\
\hline & Never & Rarely & Occasionally & Very often & $\begin{array}{l}\text { In all practical } \\
\text { activities }\end{array}$ \\
\hline 11- How often did you get feedback? & $1(3,3 \%)$ & $10(33,3 \%)$ & $11(36,7 \%)$ & $8(26,7 \%)$ & $0(0)$ \\
\hline
\end{tabular}

The results were presented as absolute numbers (percentage). 
or behavioral, need improvement to help the student obtain the desired skills during the internship ${ }^{6}$. Moreover, the feedback must contain information with guidelines for students to perform better in future activities ${ }^{17}$.

Table 4. Students' qualitative results.

\section{Topics/content}

Number of citations*

Feedback Objectives

$\begin{array}{lr}\text { To identify strengths and weaknesses } & 18\end{array}$

$\begin{array}{lr}\text { Technical improvement } & 17\end{array}$

Personal growth 4

$\begin{array}{lr}\text { Evaluation } & 2\end{array}$

Positive impact of feedback

To identify and improve weaknesses 16

$\begin{array}{lr}\text { Clinical improvement } & 10\end{array}$

Change in behavior $\quad 4$

$\begin{array}{lr}\text { To guide the studies } & 4\end{array}$

Negative impact of feedback**

$\begin{array}{lr}\text { Aggressive attitude } & 4\end{array}$

Demotivation $\quad 3$

$\begin{array}{lr}\text { No change in behavior } & 2\end{array}$

Changes observed after feedback

Improvements in anamnesis and physical examination 11

$\begin{array}{ll}\text { Change in behavior } & 8\end{array}$

Improvement in the therapeutic alliance $\quad 6$

$\begin{array}{ll}\text { Improvement in treatment } & 4\end{array}$

Improvement in the description of the medical record 3

Preceptor's qualities to provide effective feedback

$\begin{array}{ll}\text { To be respectful } & 13\end{array}$

$\begin{array}{lr}\text { To be constructive } & 9\end{array}$

$\begin{array}{lr}\text { To be clear } & 7\end{array}$

$\begin{array}{ll}\text { To be an expert on the subject } & 5\end{array}$

$\begin{array}{ll}\text { To be consistent } & 4\end{array}$

Ideal feedback

To provide constructive negative criticism $\quad 12$

\begin{tabular}{l} 
To be Individual \\
\hline
\end{tabular}

$\begin{array}{ll}\text { To be more frequent } & 7\end{array}$

$\begin{array}{ll}\text { To provide positive criticism } & 5\end{array}$

$\begin{array}{ll}\text { Oral and written feedback } & 4\end{array}$

To be polite $\quad 3$

Uncomfortable feedback **

$\begin{array}{ll}\text { Exposure in front of the patient } & 6\end{array}$

Exposure in front of colleagues $\quad 4$

None $\quad 3$

$\begin{array}{ll}\text { Criticizing without pointing out how to improve } & 1\end{array}$

*The number of citations represents the number of times the content was cited in students' responses. This decision was made because the open-ended questions did not limit the number of answers a student could provide.

**This item had a lower number of citations because most students did not answer the question, it was understood that these students did not observe negative or uncomfortable impact of the feedback. 
The frequency of feedback is very important to ensure an effective assessment; while from the preceptors' viewpoint, feedbacks were offered with a high frequency or in all practical classes, none of the students reported having received feedback in all practical classes, and few students said they frequently received them. This finding is similar to what was observed in the study by Liberman et al. ${ }^{18}$, in which the authors reported that $86.2 \%$ of surgeons gave feedback immediately after the practical activity and only $12.5 \%$ of the residents observed this frequency ${ }^{18}$. Teachers often do not understand the practice of feedback and how to convey it, so the frequency of communication may be lower than what the preceptors reported ${ }^{16}$. This reinforces the fact that being a specialist in the subject to be transmitted, as well as the length of experience in the field of medical education does not necessarily mean being a good preceptor, that is, one who encourages student reflection and promotes information about the necessary improvements. The difficulty in communicating feedback can occur when medical preceptors do not keep up-to-date; they convey the content according to the way they learned it, because they believe that their length of experience is enough to meet their pedagogical needs. This difficulty in conveying the feedbacks can affect the students' perception; the fact that the feedbacks do not have specific information on which behavior should be modified and do not contain suggestions on how to improve them, make students unaware of the feedbacks ${ }^{17}$. Therefore, it is necessary to improve the interaction between teachers and students, to provide clear, constructive and targeted feedback, so that it can be effective.

There are data that show that alone, students have difficulty understanding where and how they can improve their clinical skills; thus, the ability to give specific, timely and clear feedback is a fundamental skill for the preceptor ${ }^{17}$. For Nottingham et al. ${ }^{19}$, preceptors with less experience provided a fewer number of feedbacks to the students, while more experienced ones provided more feedbacks ${ }^{19}$, which is also observed in this study, where preceptors with longer experience in the area of health education (two years and 10 years) offered feedback in all practical classes.

In the present study, the types of feedback used by preceptors were oral, brief and constructive. Although there are several ways to provide feedback, students preferred the oral feedback, probably because it is easier to provide and receive immediately ${ }^{20}$. Other types of feedback that could be incorporated are: (1) Brief feedback, which aims to provide information on the need to change some action at the time it is observed; (2) formal feedback, in which information is given at the end of the activity, focusing on one or two specific skills, lasting from 5 to 20 minutes; (3) major, which is the guidance given in the middle of the internship or at its end, regarding more complex performances and behaviors, culminating with an action plan to attain improvements before the end of the internship cycle, lasting from 15 to 30 minutes $^{20}$.

Regarding the evaluation of the feedback effectiveness, only a quarter of the preceptors reported knowing how to evaluate. This result differs from a previous study, in which $90.9 \%$ of surgical preceptors reported evaluating the effectiveness of the feedback offered to the residents ${ }^{18}$. The feedback effectiveness can be assessed by observing the tasks and actions for which improvements were proposed and whether these were carried out, in addition to the students degree of motivation to rebuild their knowledge to perform the necessary changes. Feedback is not always accepted by students, leading to self-reflection and behavioral changes, especially when the information given by the tutors is in conflict with the students' ideas. When this happens, there may be failure in the acquisition of clinical competences and, therefore, the effectiveness that the feedback proposes is not attained ${ }^{21}$. In the present study, half of the preceptors found it difficult to provide negative feedback to students. Teachers have the perception that providing negative feedbacks can cause a break in the teacher/student relationship, in addition to affecting their popularity. To alleviate these effects, preceptors address criticisms in a lighter way, conveying messages indirectly. The lack of feedback that is clearly directed to the student may not be an effective feedback ${ }^{21}$.

On the other hand, the percentage of negative impacts caused by the provided feedbacks in this study was small. To reduce this negative impact, the feedback communication needs to be clear, respectful, non-judgmental, based on what was observed at the time and what is amenable to change, aiming to promote reflection and motivation, thus favoring changes in clinical practice ${ }^{22}$. The place where this feedback is provided seems to be the main reason for the discomfort. In a private place, feedback can be given in a clear, timely and specific way, providing an increase in student learning, as it facilitates the communication between the student and the preceptor without fear of being ridiculed by the colleagues ${ }^{23}$. Additionally, behavioral changes occur more often when there is an agreement between what was said by the teacher and the student's way of thinking; moreover, the degree of feedback acceptance is associated with the student's selfevaluation power ${ }^{24}$.

Regarding the positive impacts of feedback, the results observed in this study were positive and are similar to another study in the literature, in which $95 \%$ of the students tried to change their behavior according to the feedback that was received ${ }^{11}$. Another important point to highlight was 
that most students report that they wish the feedbacks were routine practices in practical internships. The students report that although preceptors have the knowledge and are aware of the objectives of the assessment instrument, it is not used constantly during the internships. In agreement with our results, 60 to $75 \%$ of the students in the study by Al-Mously et $\mathrm{al}^{25}$ considered the frequency with which feedback was provided was low to adequate, attributing it to the lack of a structural basis for the feedback communication to be carried out ${ }^{25}$.

The students' feedback to the preceptors does not seem to be frequent during the internship practice. Students can give feedback to preceptors about their perception of this transmissibility, providing an exchange of information to be considered and offering the necessary changes, constituting a bidirectional learning ${ }^{17}$. It was observed that preceptors prefer to receive feedback from people who have the skills to assess their professional practice performance, which is also perceived by students, who prefer to receive feedback from teachers they consider to be professional role models ${ }^{10}$. Finally, preceptors who receive feedback and use them to improve their professional performance, whether as a doctor or teacher, are more committed to providing better feedback to the students ${ }^{25}$.

We emphasize that this study sought different ways to understand the difficulties in conveying and receiving feedback according to the viewpoints of preceptors and students, respectively; however, the study has some limitations. The main one is that the sample consisted mainly of a small group of students and preceptors involved in clinical internships in Diadema. These results may not reflect the total perception of students at the USCS (Bela Vista) and not all of Diadema's practical internship preceptors. Therefore, another limitation is that it is not possible to extrapolate the results to all preceptors or students regarding the practice of feedbacks in clinical internships carried out in Diadema, nor to determine whether this practice was efficient or not.

Finally, the practical implications of the present study show that the effectiveness of feedbacks will be present when the preceptors propose corrections, promote reflections, are didactic and qualified for their communication. This can be achieved by structuring the feedback through the creation of a feedback guide, including information on how to structure an effective feedback, training on how to convey it under the supervision of trained preceptors and using practical scenarios, in which preceptors will experience situations on how to provide feedback, using the tools proposed by the guide. In order to adjust this transmissibility, it is necessary to verify how feedback is being carried out and interpreted by students in practical activities, through a feedback written by themselves on the preceptors' role when conveying them.

\section{CONCLUSION}

We conclude that the preceptors' improvement in carrying out an effective assessment through feedback is necessary. This study was able to list the necessary characteristics to perform an ideal feedback from the students' viewpoint, such as, for instance, the fact that the feedback needs to be individualized, without exposing the student; to be respectful; clear; concise, and mainly involving constructive criticism. A point to note is that most preceptors report that they frequently provide feedback, although more than half of the students said they only received feedback rarely or occasionally. This point can be seen as an effective communication failure between the preceptor and the student. Moreover, students should be encouraged to offer feedback to the preceptors on how the feedback could be more effective, as an educational alliance is necessary to have better acceptance of the feedback, which means a better understanding between preceptor and student.

\section{AUTHORS' CONTRIBUTION}

Simone Stagini was responsible for the study design, data collection, analysis and interpretation of the results and writing of the manuscript. Lena Vânia Carneiro Peres was responsible for critical review of the manuscript.

\section{CONFLICTS OF INTEREST}

The authors declare no conflicts of interest.

\section{SOURCES OF FUNDING}

The authors declare no sources of funding.

\section{REFERENCES}

1. Pagliosa FL, Da Ros MA. O relatório Flexner: para o bem e para o mal. Rev Bras Educ Med. 2008;32(4):492-9.

2. Brasil. Lei n 8.080, de 19 de setembro de 1990. Dispõe sobre as condições para a promoção, proteção e recuperação da saúde, a organização e o funcionamento dos serviços correspondentes e dá outras providências. Diário Oficial da União; 20 set 1990.

3. Brasil. Resolução CNE/CES no 4, de 7 de novembro de 2001. Institui Diretrizes Curriculares Nacionais do curso de graduação em Medicina. Diário Oficial da União; 9 nov 2001. p. 38.

4. Brasil. Resolução CNE/CES n 3, de 20 de junho de 2014. Institui Diretrizes Curriculares Nacionais do Curso de Graduação em Medicina e dá outras providências. Diário Oficial da União; 23 jun 2014. p. 8-11.

5. Panúncio-Pinto MP, de Almeida Troncon LE. Avaliação do estudante: aspectos gerais. Medicina (Ribeirao Preto, Online). 2014;47(3):314-23 [access in 4 sep 2020]. Available from: http://www.revistas.usp.br/rmrp/ article/view/86684.

6. Hardavella G, Aamli-Gaagnat A, Saad N, Rousalova I, Sreter KB. How to give and receive feedback effectively. Breathe (Sheff). 2017;13(4):327-33.

7. Trocon L. Avaliação do estudante de Medicina. Medicina (Ribeirao Preto Online). 1996; 29(4):429-33 [access in 4 sep 2020]. Available from: http:// www.revistas.usp.br/rmrp/article/view/786. 
8. Albano S, Quadri SA, Farooqui M, Arangua L, Clark T, Fischberg GM, et al. Resident perspective on feedback and barriers for use as an educational tool. Cureus. 2019;11(5)e4633.

9. Cantillon P, Sargeant J. Giving feedback in clinical settings. BMJ. 2008;337:a1961.

10. Jamshidian S, Haghani F, Yamani N, Sabri MR. Provision of feedback to medical teachers on their educational performance: perspectives of internal medicine teachers. Adv Med Educ Pract. 2019;10:85-94.

11. Bernard AW, Kman NE, Khandelwal S. Feedback in the emergency medicine clerkship. West J Emerg Med. 2011;12(4):537.

12. Dent J, Harden RM, Hunt D. A practical guide for medical teachers. Elsevier Health Sciences [London]; 2017.

13. Maia IL. Avaliação e percepção dos estudantes de Medicina sobre a mudança de atitude e desenvolvimento de competências a partir da utilização de feedback estruturado [dissertação]. Fortaleza: Centro Universitário Christus; 2018.

14. Caregnato RCA, Mutti R. Pesquisa qualitativa: análise de discurso versus análise de conteúdo.Texto \& Contexto Enferm. 2006;15(4):679-84.

15. Tong A, Sainsbury $P$, Craig J. Consolidated criteria for reporting qualitative research (COREQ): a 32-item checklist for interviews and focus groups. Int J Qual Health Care. 2007;19(6):349-57.

16. Burgess $A$, Mellis C. Feedback and assessment for clinical placements: achieving the right balance. Adv Med Educ Pract. 2015;6:373.

17. Carr BM, O'Neil A, Lohse C, Heller S, Colletti JE. Bridging the gap to effective feedback in residency training: perceptions of trainees and teachers. BMC Med Educ. 2018;18(1):225.
18. Liberman AS, Liberman $M$, Steinert $Y$, McLeod P, Meterissian A. Surgery residents and attending surgeons have different perceptions of feedback. Med Teach. 2005;27(5):470-2.

19. Nottingham S, Henning J. Feedback in clinical education, part II: approved clinical instructor and student perceptions of and influences on feedback. J Athl Train. 2014;49(1):58-67.

20. Branch Jr WT, Paranjape A. Feedback and reflection: teaching methods for clinical settings. Acad Med. 2002;77(12 Part 1):1185-8.

21. Telio S, Ajjawi R, Regehr G. The "educational alliance" as a framework for reconceptualizing feedback in medical education. Acad Med. 2015;90(5):609-14.

22. Ramani S, Krackov SK. Twelve tips for giving feedback effectively in the clinical environment. Med Teach. 2012;34(10):787-91.

23. Ntuli S, September NN, Sithole N. South African podiatry students' perceptions of feedback given as part of clinical training. J Foot Ankle Res. 2018;11(1):36

24. Schartel SA. Giving feedback: an integral part of education. Best Pract Res Clin Anaesthesiol. 2012;26(1):77-87.

25. Al-Mously N, Nabil NM, Al-Babtain SA, Abbas MAF. Undergraduate medical students' perceptions on the quality of feedback received during clinical rotations. Med Teach. 2014;36(Suppl 1):S17-23. 